\title{
Meningkatkan Hasil Belajar Siswa pada Pembelajaran IPS dengan Metode Problem Solving
}

\author{
Emilia Fernanda \\ SDN 21 Batang Anai Kabupaten Padang Pariaman
}

\begin{abstract}
Abstrak
Students of grade 4 SDN 21 Batang Anai Kabupaten Padang Pariaman in learning process used to be passive. Teacher also often used the expository method. This is a classroom action research with two cycles that aimed to improve students' learning achievement (cognitive, affective, and psychomotor domains) through implementation of problem solving method in social subject learning. In cycle I, students' score of cognitive domains is 6.46, students' score of affective domain is 6.49 , and students' score of psychomotor domain is 6.49. In cycle II, students' score of cognitive domains is 8.23 , students' score of affective domain is 8.24 , and students' score of psychomotor domain is 8.03 .
\end{abstract}

Kata Kunci: learning achievement, problem solving, social subject.

\section{PENDAHULUAN}

Ilmu Pengetahuan Sosial (IPS) merupakan salah satu mata pelajaran yang diberikan mulai dari SD/MI/SDLB sampai ke perguruan tinggi. IPS mengkaji seperangkat peristiwa, fakta, konsep, dan generalisasi yang berkaitan dengan isu sosial. Pada jenjang SD/MI mata pelajaran IPS memuat materi Geografi, Sejarah, Sosiologi dan Ekonomi. Melalui mata pelajaran IPS, peserta didik diarahkan untuk dapat menjadi warga negara Indonesia yang demokratis dan bertanggung jawab, serta warga dunia yang berkemampuan sebagai berikut: 1) Mengenal konsep-konsep yang berkaitan dengan kehidupan masyarakat dan lingkungan, 2) memiliki kemampuan dasar untuk berpikir logis dan rasa ingin tahu, inkuiri, memecahkan masalah, dan keterampilan dalam kehidupan sosial, 3) memilikikomitmen, kesadaran terhadap nilai-nilai sosial kemanusian, 4) memiliki kemampuan berkomonikasi, bekerja sama berkopetensi dalam masyarakat majemuk (Depdiknas, 2006). Secara mendasar pembelajaran IPS berkenaan dengan kehidupan manusia yang melibatkan segala tingkah laku dan kebutuhannya. IPS berkenaan dengan cara manusia menggunakan usaha memenuhi kebutuhan materialnya, memenuhi kebutuhan budayanya, kebutuhan jiwanya, pemanfaatan sumber daya yang ada dimuka bumi, mengatur kesejahteraan, pemerintahannya, dan lain sebagainya yang mengatur serta mempertahankan kehidupan masyarakat.

IPS pada jenjang pendidikan dasar memfokuskan kajiannya kepada hubungan antar manusia dan proses membantu pengembangan kemampuan dalam hubungan tersebut. Pengetahuan, keterampilan, dan sikap yang dikembangkan melalui kajian ini ditunjukan untuk mencapai keserasian dan keselarasan dalam kehidupan masyarakat. Mata pelajaran IPS di SD bertujuan agar peserta didik mampu mengembangkan pemahaman tentang perkembangan masyarakat Indonesia sejak masa lalu hingga masa kini sehingga peserta didik memiliki kebanggaan sebagai bangsa 
Indonesia dan cinta tanah air. Pembelajaran IPS akan menjadi suatu pengetahuan, keterampilan, serta pemahaman sikap dan nilai bagi peserta didik, jika guru mampu menentukan cara terbaik dalam menyampiakan materi yang terdapat dalam mata pelajaran IPS tersebut. Salah satu upaya yang dapat dilakukan guru adalah dengan menggunakan metode yang berpariasi.

Dampak IPS terhadap kehidupan bermasyarakat, masih belum begitu tampak. Perwujudan nilai-nilai sosial yang dikembangkan di sekolah belum tampak dalam kehidupan sehari-hari peserta didik, keterampilan sosial para lulusan pendidikan dasar masih memprihatinkan, partisipasi peserta didik dalam berbagai kegiatan kemasyarakatan semakin menyusut. Kemampuan peserta didik dalam menanggapi masalah-masalah sosial belum terlihat. Hal tersebut sesuai dengan kenyataan yang peneliti alami, peserta didik dalam proses pembelajaran hanya pasif mendengarkan apa yang disampaikan oleh guru. Dalam proses pemebelajaran peserta ribut dan beberapa orang peserta didik asik bermain dengan teman sebangkunya, hal ini disebabkan oleh peserta didik merasa jenuh dan tidak konsentrasi dalam mengikuti proses pembelajaran. Peserta didik belum mampu untuk manyampiakan ide-ide yang ada pada pikirannya dalam bentuk pertanyaan. Jika ada kesempatan untuk bertanya dari guru peserta didik lebih banyak diam, solah-olah meraka mengerti dengan pelajaran yang dipelajari. Sementara, apabila guru mengajukan pertanyaan seputar materi pembelajaran yang telah disampaikan, sebagian besar peserta didik tidak mampu menjawab pertanyaan yang diajukan guru.

Dalam mengerjakan tugas peserta didik lebih banyak mengharapkan bantuan dari teman sebangkunya yang pandai tanpa mau berpikir sendiri jawaban yang dimiliknya. Peserta didik baru mampu menghafal fakta, konsep, prinsip, hukum, teori, dan gagasan inovatif lainnya pada tingkat ingatan, mereka belum dapat menggunakan dan menerapkannya secara efektif dalam pemecahan masalah sehari-hari yang sangat dekat dengan kehidupannya. Dari segi proses pembelajaran, guru dalam pembelajaran IPS pada umumnya hanya menggunakan metode ceramah, tanya jawab, dan penugasan. Sehingga anak beranggapan bahwa pelajaran IPS hanya pelajaran hafalan. Salah satu metode yang tepat digunakan dalam pembelajaran IPS adalah metode problem solving. Metode ini sangat cocok dengan pembelajaran IPS karena secara mendasar pengajaran IPS berkenaan dengan kehidupan manusia yang melibatkan segala tingkah laku dan kebutuhannya, dalam IPS juga mempelajari masalah-masalah sistem kehidupan manusia dipermukaan bumi ini yang diperlukan pemecahan. Selain itu penggunaan metode problem solving sebagai salah satu cara untuk memotivasi peserta didik dalam belajar IPS. Serta melatih pola pikir peserta didik agar peserta didik terbiasa kritis, punya kepekaan sosial yang tinggi serta dapat memecahkan persoalan-persoalan yang dihadapinya.

Menurut Pasaribu, dkk (1986), metode problem solving adalah metode yang mendorong peserta didik untuk berpikir secara sistematis dengan menghadapkannya kepada problemaproblema dalam kehidupan pribadi ataupun masalah kelompok untuk dipecahkan secara bersamasama. Martinis (2008) menjelaskan beberapa kuunggulan metode problem solving sebagai berikut: 1) Mengembangkan pemecahan yang bermakna dalam rangka mengembangkan materi ajar, 2) pemecahan masalah melibatkan peserta didik secara aktif dalam belajar, 3) pemecahan masalah membantu peserta didik belajar bagaimana mentransfer ilmu pengetahuan mereka ke dalam dunia persoalan nyata, 4) pemecahan masalah membantu peserta didik mengembangkan pengetahuan baru untuk kepentingan persoalan berikutnya, 5) pemecahan masalah dapat mengembangkan keterampilan berpikir kritis peserta didik dan kemampuan mereka mengadaptasi situasi pembelajaran baru, 6) pemecahan masalah membantu peserta didik mengevaluasi pemahamannya dan mengidentifikasikan alur berpikirnya. 
Dalam mengajarkan metode problem solving guru harus mengikuti langkah-langkah pembelajaran dengan metode problem solving dengan sistematis. Adapun langkah-langkah tersebut di jelaskan oleh Jhon Dewai (dalam Sanjaya, 2008) sebagai berikut: 1) merumuskan masalah, yaitu langkah peserta didik merumuskan masalah yang akan dipecahkan, 2) menganalisa masalah, yaitu langkah peserta didik meninjau masalah secara kritis dari berbagai sudut pandang, 3) merumuskan hipotesis yaitu langkah peserta didik merumuskan berbagai kemungkinan pemecahan sesuai dengan pengetahuan yang dimilkinya, 4) mengumpulkan data, yaitu langkah peserta didik mencari dan mengambarkan informasi yang diperlukan untuk pemecahan masalah, (5) pengujuian hipotesis, yaitu langkah peserta didik mengambil atau merumuskan kesimpulan sesuai dengan penerimaan dan penolakan hipotesis yang diajukan, 6) merumuskan rekomendasi pemecahan masalah, yaitu langkah peserta didik menggambarkan rekomendasi yang dapat dilakukan sesuai rumusan hasil pengujian hipotesis dan rumusan kesimpulan.

Hasil belajar merupakan dasar untuk menentukan tingkat keberhasilan peserta didik dalam memahami materi pelajaran. Hasil belajar merupakan sesauatu yang diperoleh, dikuasai, atau dimiliki peserta didik setelah proses pembelajaran berlangsung. Guru memegang kendali utama agar proses pembelajaran berhasil dan tujuan pembelajaran dapat tercapai, sehingga hasil belajar dapat meningkat. Untuk itu guru harus memiliki keterampilan dalam mengajar, keterampilan untuk mengelola tahapan pembelajaran, keterampilan memanfaatkan metode yang ada, salah satunya metode problem solving, keterampilan memanfaatkan media, dan keterampilan mengalokasikan waktu. Hasil belajar merupakan tolak ukur yang digunakan untuk menentukan tingkat keberhasilan peserta didik dalam proses pembelajaran. Apabila telah terjadi perubahan tingkah laku pada diri seorang peserta didik, maka seorang peserta didik dapat dikatakan telah berhasil dalam belajar sebagaimana dikemukakan oleh Hamalik (2008) bahwa hasil belajar adalah tingkah laku yang timbul, misalnya dari tidak tahu menjadi tahu, timbulnya pertanyaan baru perubahan dalam tahap kebiasaan keterampilan, kesanggupan menghargai, perkembangan sikap sosial, emosional, dan pertumbuhan jasmani.

\section{METODE}

Penelitian ini dilaksanakan di SDN 21 Batang Anai Kabupaten Padang Pariaman. Subjek pada penelitian ini adalah peserta didik kelas IV SD Negeri 21 Batang Anai Kabupaten Padang Pariaman yang berjumlah 30 orang. Penelitian yang penulis lakukan bertujuan untuk meningkatkan proses pembelajaran IPS di kelas IV SD Negeri 21 Batang Anai Kabupaten Padang Pariaman dengan menggunakan metode problem solving. Penelitian difokuskan pada perencanaan, pelaksanaan, dan penilaian proses pembelajaran dengan menggunakan pendekatan kualitatif. Jenis penelitian yang penulis lakukan adalah Penelitian Tindakan Kelas (PTK). Prosedur pelaksanaan penelitian ini mengikuti empat tahapan, yaitu perencanaan, pelaksanaan, pengamatan, dan refleksi. Data penelitian ini dikumpulkan dengan menggunakan observasi, wawancara, hasil tes dan instrumen.

\section{HASIL}

\section{Deskripsi Data}

\section{Deskripsi Siklus I}

\section{a. Perencanaan}

Penggunaan metode problem solving dalam perencanaan pembelajaran IPS disusun dan diwujudkan dalam Rencana Pelaksanaan Pembelajaran (RPP). Perencanaan ini disusun berdasarkan program semester kedua sesuai dengan penelitian berlangsung. Perencanaan pembelajaran disusun untuk satu kali pertemuan atau 4 x 35 menit. Materi diambil dari Kurikulum Tingkat Satuan Pendidikan (KTSP) tingkat SD 2006 mata pelajaran IPS kelas IV semester II. 


\section{b. Pelaksanaan}

Materi pembelajaran yang dilaksanakan pada siklus I adalah masalah kemiskinan dengan menggunakan metode problem solving. Standar kompetensinya yaitu mengenal sumber daya alam, kegiatan ekonomi, dan kemajuan teknologi di lingkungan kabupaten/kota dan propinsi, sedangkan kompetensi dasarnya adalah mengenal permasalahan sosial di daerahnya. Indikator pembelajaran yang harus dicapai peserta didik adalah peserta didik dapat: 1) Menyebutkan pengertian masalah sosial, 2) menyebutkan pengertian kemiskinan, 3) menyebutkan penyebab terjadinya kemiskinan, 4) mendiskusikan pemecahan masalah kemiskinan. Untuk mencapai indikator yang telah ditentukan maka peneliti selaku praktisi menggunakan metode problem solving dalam pembelajaran dengan mengikuti langkah-langkah yang telah ditentukan.

\section{c. Pengamatan}

Pengamatan terhadap tindakan penggunaan metode problem solving dalam pembelajaran IPS di kelas IV SDN 21 Batang Anai dilakukan bersamaan dengan tindakan. Pengamatan dilakukan secara terus menerus mulai dari tindakan pertama sampai tindakan berakhir. Kegiatan guru dalam pembelajaran dinilai dengan menggunakan lembaran pengamatan dengan persentase perolehan skor $61 \%$. Pengamatan dilakukan secara terus menerus mulai dari tindakan pertama sampai tindakan berakhir. Kegiatan peserta didik dalam pembelajaran dinilai dengan menggunakan lembaran pengamatan dengan persentase perolehan skor $59 \%$. Hasil belajar peserta didik kelas IV SDN 21 Batang Anai. yang diperoleh selama pembelajaran pada siklus I ranah kognitif baru mencapai nilai rata-rata kelas 6,46, nilai ratarata pada ranah psikomotor baru mencapai 6,49 dan ranah afektif baru mencapai nilai rata-rata 6,49 dimana target yang diinginkan peneliti adalah 6,5 (standar ketuntasan sekolah) sedangkan tingkat ketuntasan kelas baru mencapai $67 \%$, dimana target yang diinginkan peneliti adalah $75 \%$. Masih banyak peserta didik yang mendapat nilai dibawah nilai 6,5 yaitu 10 orang dengan jumlah peserta didik yang hadir pada saat tindakan 30 orang.

\section{d. Refleksi}

Perencanaan pembelajaran belum terlaksana dengan baik. Sebagian dari langkah pada perencanaan terlaksana sesuai yang diinginkan. Tapi terdapat beberapa langkah yang tidak berjalan baik. Penyajian materi dengan menggunakan metode problem solving dalam pembelajaran IPS belum terlaksana dengan baik. Ada ketimpang tindihan beberapa langkah. Seperti dalam menjelaskan pengertian masalah sosial. Sebaiknya dalam RPP pengertian masalah sosial baru macam-macam masalah sosial yang mereka ketahui. Sebelum peserta didik melakukan diskusi diberikan penjelasan tentang langkah-langkah metode problem solving dengan jelas agar peserta didik tidak mengalami kebingungan dalam mengisi LKS.

Dalam pembagian kelompok guru seharusnya memperhatikan kemampuan peserta didik. Karena ada satu kelompok yang terdiri dari peserta didik yang memiliki kemampuan rendah sehingga dalm diskusi tidak menghasilkan hasil yang maksimal. Sumber yang digunakan untuk mencari data hanya satu sebaik sumber yang digunakan harus lebih dari satu. Penggunaan waktu agar diefesienkan. Hasil tes siklus I menunjukkan belum keseluruhan peserta didik memahami materi yang diberikan. Masih ada beberapa peserta didik yang masih mendapatkan nilai di bawah rata-rata. Berdasarkan pengamatan, maka tujuan pembelajaran yang diharapkan pada pembelajaran siklus I belum tercapai dengan baik. Hal itu ditemui pada pertemuan pertama. Upaya menggunakan metode problem solving dapat menentukan langkahlangkah proses pembelajaran yang akan ditargetkan pada siklus II. 


\section{Deskripsi Siklus II}

\section{a. Perencanaan}

Sama halnya dengan siklus I sebelum pelaksanaan pembelajaran terlebih dahulu peneliti membuat perencanaan pelaksanaan pembelajaran (RPP). Perencanaan yang dibuat pada siklus II pada garis besarnya sama dengan perencanaan pembelajaran siklus I. Perbedaan yang terdapat pada siklus dua ini adalah materi yang akan diajarkan yaitu masalah kejahatan. Indikator yang ingin dicapai dalam pembelajaran ini adalah 1) menyebutkan pengertian kenakalan remaja, 2) menyebutkan penyebab terjadinya kenakalan remaja, 3) mendiskusikan pemecahan masalah kenakalan remaja. 4) membuat kliping tentang masalah sosial yang terjadi di kota Padang. Pada kegiatan awal, guru menyiapkan peserta didik untuk belajar secara klasikal, berdo'a dan absensi, peserta didik mendengarkan tujuan pelajaran dan apersepsi yaitu membangkitkan skemata peserta didik dengan tanya jawab tentang pelajaran yang telah dipelajari.

\section{b. Pelaksanaan}

Pelaksanaan pembelajaran IPS pada siklus II, dengan menggunakan metode problem solving di kelas IV SDN 21 Batang Anai. Pembelajaran pada siklus kedua dilaksanakan dalam satu kali pertemuan, pertemuan dilaksanakan pada hari Selasa 4 Maret 2014 dengan waktu 4 x 35 Menit.

\section{c. Pengamatan}

Pengamatan terhadap tindakan penggunaan metode problem solving dalam pembelajaran IPS di kelas IV SDN 21 Batang Anai dilakukan bersamaan dengan tindakan. Hal ini dilaksanakan secara intensif, objektif, dan sistematis. Pengamatan dilakukan pada waktu pelaksanaan tindakan pembelajaran IPS oleh kepala sekolah. Kepala sekolah bertugas mangamati kegiatan aktifitas guru dan kepala sekolah bertugas mengamati akifitas peserta didik dalam pembelajaran. Kegiatan guru dalam pembelajaran dinilai dengan menggunakan lembaran pengamatan dengan persentase yang yang diperoleh guru $87 \%$. Pada kegiatan akhir peserta didik melakukan tes yang diberikan guru dalam bentuk esai, dalam melakukan tes peserta didik waktu yang sudah disediakan sudah cukup. Secara umum keberhasilan peserta didik pada siklus II pada ranah kognitif sudah mencapai rata-rata 8,23. Sedangkan untuk ranah afektif nilai rata-rata peserta didik 8,24 . Untuk ranah psikomotor pada siklus II ini nilai ratarata 8,03 dengan persentase ketuntasan kelas $83 \%$.

\section{d. Refleksi}

Kegiatan refleksi dilakukan secara kolaboratif antara peneliti, kepala sekolah setiap pembelajaran berakhir. Pada kesempatan ini temuan dan hasil pengamatan peneliti dibahas bersama. Refleksi tindakan siklus II ini mencakup refleksi terhadap perencanaan, pelaksanaan, evaluasi dan hasil yang diperoleh oleh peserta didik. Refleksi terhadap perencanaan yakni sebagai berikut: dilihat dari hasil paparan siklus II diketahui bahwa perencanaan pembelajaran sudah lebih baik dari siklus I, serta dilaksanakan sesuai langkah-langkah yang tertulis dalam perencanaan.

\section{PEMBAHASAN}

\section{Siklus I}

Penyebab adanya minat belajar peserta didik menurun adalah karena guru masih menggunakan pembelajaran yang bersifat konvensional, sehingga peserta didik menjadi pasif dalam belajar. Apabila minat belajar peserta didik menurun secara tidak langsung nilai peserta didik juga akan menurun. Kegiatan pembelajaran dibagi dalam 3 tahap pembelajaran yaitu tahap awal, tahap 
inti, dan tahap akhir. Hasil belajar peserta didik kelas IV SDN 21 Batang Anai, Kabupaten Padang Pariaman. yang diperoleh selama pembelajaran pada siklus I adalah: ranah kognitif baru mencapai nilai rata-rata kelas 6,46 nilai rata-rata pada ranah psikomotor baru mencapai 6,49 rincian nilai psikomotor dapat dilihat pada lampiran 3 dan ranah afektif baru mencapai nilai rata-rata 6,49 dimana target yang diinginkan peneliti adalah 6,5 (standar ketuntasan sekolah) sedangkan tingkat ketuntasan kelas baru mencapai 67\%, dimana target yang diinginkan peneliti adalah 75\% (Susanto 2007:41). Masih banyak peserta didik yang mendapat nilai dibawah nilai 6,5 yaitu 10 orang dengan jumlah peserta didik yang hadir pada saat tindakan 30 orang sehingga perlu dilakukan tindakan siklus II.

\section{Siklus II}

Penilaian merupakan hal yang tidak bisa dipisahkan dengan proses pembelajaran. Penialaian pembelajaran IPS dilakukan secara terus menerus selama proses pembelajaran berlangsung yang meliputi aspek kognitif, afektif dan psikomotor. Melaksanakan penilaian khususnya yang berhubungan dengan hasil belajar peserta didik adalah salah satu kemampuan dasar yang harus dimiliki oleh seorang guru. Penilaian adalah kegiatan untuk mengetahui perkembangan, kemajuan, atau hasil belajar peserta didik selama proses pembelajaran. Dari hasil penilaian pembelajaran pada siklus siklus II hasil belajar peserta didik sudah mencapai nilai yang ditargetkan yakni pada ranah kognitif sudah mencapai rata-rata 8,23 dengan persentase ketuntasan kelas $83 \%$. Sedangkan untuk ranah afektif nilai rata-rata peserta didik 8,24 dengan persentase ketuntasan kelas $86 \%$. Untuk ranah psikomotor pada siklus II ini nilai rata-rata 8,03 dengan persentase ketuntasan kelas $86 \%$. Jadi, hasil belajar peserta didik dapat dilihat dari kemampuannya dalam mengingat pelajaran yang telah disampaikan selama pembelajaran dan bagaimana peserta didik tersebut bisa menerapkannya serta mampu memecahkan masalah yang timbul sesuai dengan apa yang telah dipelajarinya.

\section{KESIMPULAN}

Bentuk rancangan pembelajaran IPS dengan menggunakan metode problem solving berdasarkan pada langkah-langkah metode problem solving yang terdiri dari enam langkah. Pembelajaran menggunakan metode problem solving dibagi atas tiga tahapan yaitu kegiatan awal, kegiatan inti, dan kegiatan akhir. Bentuk pelaksanaan metode problem solving adalah: pelaksanaan pembelajaran IPS dengan menggunakan metode problem solving harus sesuai dengan langkahlangkah pembelajaran yang telah dirancang. Penilaian pembelajaran IPS dengan metode problem solving bertujuan untuk memberikan umpan balik baik kepada guru, peserta didik, orang tua maupun lembaga pendidikan yang berkepentingan. Penilaian dalam pembelajaran IPS mencakup tiga aspek yaitu: aspek kognitif, afektif, dan psikomotor. Pembelajaran pemecahan masalah (problem solving) dapat meningkatkan hasil belajar peserta didik, hal ini terlihat dari pencapaian hasil belajar peserta didik pada akhir tindakan. Dimana dari aspek kognitif hasil belajar peserta didik terjadi peningkatan dari rata-rata pada siklus I 6,46 menjadi rata-rata 8,23 pada siklus II. Sedangkan untuk ranah afektif nilai rata-rata peserta didik meningkat dari 6,49 pada siklus I menjadi 8,24 pada siklus II. Untuk ranah psikomotor pada terjadi peningkatan nlai dari rata-rata 6,49 pada siklus I meningkat menjadi 8,03 pada siklus II.

\section{SARAN}

Bentuk pembelajaran IPS dengan menggunakan metode problem solving layak dipertimbangkan oleh guru untuk menjadi pembelajaran alternatif yang dapat digunakan sebagai referensi dalam memilih metode pembelajaran. Bagi guru yang ingin menerapkan pembelajaran dengan menggunakan metode pembelajaran idealnya dalam memberikan materi disesuaikan dengan konteks sehari-hari, perlu lebih kreatif dalam merancang pembelajaran yang sesuai dengan situasi dunia nyata, serta perlu memberikan perhatian, bimbingan, dan motivasi belajar secara sunguh- 
sungguh kepada peserta didik yang berkemampuan kurang dan pasif dalam kelompok, karena peserta didik yang demikian sering menggantungkan diri pada temannya. Kepada sekolah dan pejabat terkait kiranya dapat memberikan perhatian kepada guru terutama dalam meningkatkan hasil belajar dalam proses pembelajaran.

\section{DAFTAR RUJUKAN}

Depdiknas. (2006). Kurikulum Tingkat Satuan Pendidikan. Jakarta: Depdiknas.

Hamalik, Oemar. (2005). Kurikulum dan Pembelajaran. Jakarta: Bumi Aksara.

Ischak, dkk. (1997). Materi Pokok Pendidikan IPS di SD. Jakarta: Debdikbud.

Pasaribu. (1986). Dedaktik dan Metodik. Bandung. Tarsito.

Sanjaya, Wina. (2008). Strategi Pembelajaran Berorentasi Standar Proses Pendidikan. Jakarta: Kencana Prenada Media Group.

Solihatin, Etin dan Raharjo. (2008). Cooperative Learning Analisis Pembelajaran IPS. Jakarta: Bumi Aksara.

Sudjana, Nana. (2004). Dasar-dasar Proses Belajar Mengajar. Bandung: Sinar Baru Algesindo

Wahab, Abdul Aziz. (2007). Metode dan Model Belajar Mengajar IPS. Bandung: Alfabeta.

Yamin, Martinis dan Bansu Ansari. (2008). Taktik Mengembangkan Kemampuan Individual Siswa. Jakarta: Gaung Persada Press. 